\title{
Rasgos ensayísticos en el epistolario de Jovellanos. La declaración de un estilo ensayístico
}

\author{
Lucía Díaz Sancho \\ Instituto Feijoo de Estudios del Siglo XVIII
}

Hablar de ensayo en el siglo XvIII como género literario puede parecer un auténtico anacronismo, si tenemos en cuenta que no será hasta bien avanzado el siglo XIX el momento en que se empieza a tener conciencia del género, y particularmente con autores como Azorín u Ortega que se consideran ensayistas y califican a sus obras de ensayo. No obstante, sus rasgos más sobresalientes se pueden rastrear en épocas anteriores, en autores que imprimen a sus escritos una actitud que bien se puede calificar de ensayística.

Uno de estos autores es, sin lugar a dudas, Gaspar Melchor de Jovellanos. Autor prolífico que sabe imprimir a sus escritos un tono personal, actual y atento al lector. No en vano estamos ante uno de esos personajes fundamentales en su momento pero que constantemente reclaman la atención de muy variados lectores y estudiosos atraídos por la continuada originalidad y actualidad de los temas que trata, en una prosa elaborada pero cercana, en la que la figura del receptor está siempre presente, dado su interés por mostrar, divulgar, reformar y hacer partícipe al otro de sus propias ideas.

Su magna obra ha sido analizada desde los más variados puntos de vista, constituyéndose en documentos de incuestionable valor para abordar el estudio de la política, historia, derecho, economía, literatura,... en el periodo ilustrado. Son memorias, elogios, discursos, oraciones que permiten observar la actitud de este ilustrado ante muy diversas cuestiones, una actitud que se manifiesta en una prosa clara, sencilla y elaborada, como muestra del ideal estilís- 
tico que se perseguía en el siglo y que evidencia una actitud, que bien se puede calificar de ensayística.

Su correspondencia, aunque de carácter privado, no se aleja de la concepción por la búsqueda de un estilo propio, sencillo y cuidado, y en no pocas ocasiones podemos comprobar cómo Jovellanos reflexiona sobre su estilo y aboga por el más personal que encuentra, en esa continuada charla que a lo largo de su vida mantiene con muy diversos corresponsales. Es una correspondencia en la que la actitud ensayística de Jovellanos se hace evidente como iremos viendo, en una declarada voluntad estilística.

La correspondencia de Jovellanos abarca una gran cantidad de asuntos a tratar con muy variados corresponsales: desde la carta-respuesta meramente oficial, hasta aquellas de mayor interés para el caso que nos ocupa, en que aborda temas familiares, jurídicos, cuestiones filológicas y literarias, historia, etc. en un tono enteramente subjetivo y personal, pudiendo ver su verdadero yo, a la vez que asistimos a su elaborado discurrir de ideas o su preocupación por el lector. En definitiva, cartas en las que se pueden rastrear muchos de los rasgos propios del ensayo tal y como hoy lo conocemos.

Se puede objetar que correspondencia privada y ensayismo, que supone pensar en una recepción amplia y heterogénea, no tienen sentido. Igualmente, se podría negar esa actitud ensayística en un momento en que no existe conciencia de ensayo, y por lo tanto su caracterización es dificultosa. Dos cuestiones que se resuelven teniendo en cuenta la profunda preocupación que Jovellanos siente por imprimirles un estilo personal, claro y adecuado al tema de que esté tratando en cada momento. Una voluntad de estilo que nos permiten ver en ellas una actitud ensayística.

Sin embargo, uno de los rasgos que en la actualidad se señalan como propios del ensayo es el hecho de ser escritos cuyo ámbito de recepción es múltiple y heterogéneo. El ensayista toma un tema y lo muestra de modo que, independientemente del conocimiento del receptor sobre el asunto allí plasmado, el lector lo entienda, le haga pensar y llegue a tomar las reflexiones allí enunciadas como algo propio.

Cuando Jovellanos escribe sus cartas, dada su privacidad, conoce al receptor, sabe cuáles son sus intereses y motivaciones, y parte en muchas ocasiones de un conocimiento por ambos compartidos. El hecho de ser privada, limita notablemente la repercusión de las ideas expuestas dado que no son cartas concebidas para la publicación. Sin embargo, a medida que nos adentramos en su estudio, observamos que en no pocas ocasiones, se habla de su repercusión sobre un grupo mayor del inicialmente supuesto, e incluso en algún momento hay quien le propone la posibilidad de darlas a la luz a un amplio 
público, reconociendo el interés general que las ideas en ellas plasmadas conllevan.

En este sentido, Ceán Bermúdez, uno de los muchos que reciben cartas del gijonés, quizá haya sido uno de los primeros en considerar la posibilidad y lo idóneo de darlas al público. La razón, el interés y trascendencia de las variadas noticias expuestas por don Gaspar, que contribuirían al enrequecimiento y felicidad de la sociedad, lamentando que éstas se quedasen reducidas al ámbito de lo estrictamente privado y familiar. Como vemos, Ceán se hace cargo de que es una correspondencia privada, pero las ideas que en ellas se contienen pueden ampliar el campo de conocimiento de un amplio público; la actitud propia del ilustrado se encuentra armoniosamente conviviendo con la actitud ensayística. La respuesta de Jovellanos es la que sigue:

Mi querido Ceán: no sé cómo dices que mis cartas merecerían imprimirse. Escribo tan deprisa que apenas merecerán leerse. De esto resulta también muy poco orden y algunos olvidos; bien lo prueba esta que servirá de complemento a las otras y singularmente a la última ${ }^{1}$.

Tras estas palabras del asturiano se puede ocultar una falsa modestia. Nadie duda de la admiración y amistad que estos dos personajes se profesaban, pero en su momento Jovellanos se había convertido en autoridad para diversos temas, que hacía que sus ideas salieran del reducido ámbito emisor-receptor concreto, para darse, hablarse en círculos más amplios, como tendremos ocasión de ver.

En cualquier caso, en estas palabras de Jovellanos nos encontramos con una auténtica reflexión sobre su estilo, entresacando algunos rasgos que forman parte del género ensayístico tal y como hoy lo conocemos: la brevedad, un voluntario desorden, las digresiones, o el carácter dialógico. Estilo cuidado, personal y elaborado que es el que otorga a su correspondencia un interés mayor que el que se reduce sólo a completar un estudio biográfico; la abundancia de temas que en ellas trata tienen como lugar común su cuidado estilo, un estilo que surge desde su propio modo de reflexionar, y que es el que logra la continuada originalidad y actualidad de la misma:

${ }^{1}$ Gijón, 23 de septiembre de 1795, de Jovellanos a Juan Agustín Ceán Bermúdez. Todas las referencias de las cartas proceden de Gaspar Melchor de Jovellanos, Obras Completas, tomos II-V, Correspondencia edición crítica, introducción y notas de José Miguel Caso González, Oviedo, Centro de Estudios del Siglo XVIIIAyuntamiento de Gijón (1986-1990). A partir de este momento indicaré la fecha de la carta y los corresponsales de la misma. 
El carácter íntimo y privado de esta correspondencia, no pensada para la impresión, le da un valor inmenso, al ser el vehículo tras el cual se vuelca toda la personalidad del autor. A esto hay que unir la amplitud de temas que trata y las opiniones que emite sobre infinidad de problemas del momento.

(...) Don Gaspar se vuelca por entero en ellas, lo mismo cuando escribe a su hermano sobre asuntos de Gijón, a su amigo íntimo González de Posada, que cuando le pone los puntos sobre las íes a un falso y desagradecido amigo como el obispo de Lugo Peláez Caunedo. Toda la personalidad de Jovellanos, compleja como la de cualquiera, pero más en quien está ocupado en tantas cosas distintas, queda clara y nítida como en las epístolas².

Parece claro que la prosa que Jovellanos utiliza en estas cartas privadas, familiares goza del aprecio de todos por ser una prosa en la que la voluntad estilística, la subjetividad traducida en estilo personal, a la vez que muestra su razonamiento atrae al lector, más allá de su corresponsal concreto, y más allá del momento que le tocó vivir.

Retomando la idea de privacidad de esta correspondencia de Jovellanos, sabemos quiénes eran los directos lectores de estas cartas, a quiénes se dirigía. Esto implica que Jovellanos en el momento en que las redactaba conocía bien cuáles eran los intereses, las actitudes y conocimientos de sus receptores, hecho este que parece chocar frontalmente con el ya señalado rasgo del ensayo que apunta a aun lector múltiple y heterogéneo. Sin embargo, son numerosas las cartas en las que, aun sabiendo quiénes son sus receptores y cuáles sus actitudes, no duda en explicar hasta el último detalle, como si pensase que sus ideas no tendrían un reducido límite de repercusión. Veamos un ejemplo:

De este cotejo he decidido que el número y armonía de los versos no tanto penden de las voces que entran en la composición de los versos, cuanto en su colocación y especialmente en la disposición de las pausas, o por decirlo con la voz técnica cesuras que debe haber en cada verso ${ }^{3}$.

El destinatario de esta carta es Meléndez Valdés, el asunto poesía, motivo una crítica, el interés mostrar su propia teoría poética. El tono general que utiliza en la carta es declaradamente sencillo y, lo que más sorprende, es que aún conociendo Jovellanos que Meléndez es una de las figuras más sobresalientes de la poesía del momento, evita utilizar tecnicismos y cuando los utiliza, como es

${ }^{2}$ Op. cit. Caso González, Obras Completas, Tomo II, pág. 14.

${ }^{3}$ Op. cit. Sevilla, ¿junio? de 1777, de Jovellanos a Juan Meléndez Valdés. 
el caso de cesura, no duda en explicarlo, traducirlo a un lenguaje ampliamente entendido. Tal vez se trate del afán divulgativo del ilustrado, pero tal vez esté pensando en una recepción mayor que tendría en Meléndez el punto de arranque para comentar, debatir sus ideas poéticas.

Estas cartas privadas, que evidencian la imperiosa necesidad que don Gaspar sentía de comunicarse, de charlar de temas diversos con sus amigos, nos permiten ver en múltiples ocasiones que el ámbito de recepción se multiplicaba no pocas veces, siendo sabedor de ello el propio emisario.

Así, en carta privada a uno de sus más íntimos amigos, Carlos González Posada, con fecha de 1805, vemos como la diálogo que mantienen para comentar lo que una estampa sobre el Cristo de Candás les parece, dice:

Todavía en esta carta hablaré de la nueva estampa, porque usted en la del 28 me da mucho para ello. El asunto es digno del piadoso objeto y la discusión agradable, porque es de las artes que ambos amamos. Si otros, por lo mismo, creyeron que nos ocupamos de bagatelas, peor para ellos ${ }^{4}$.

Las cartas sobre este asunto son varias, y de esta deducimos que las ideas que en ellas se comentan habían salido del ámbito privado y habían servido para comentarios diversos, en este caso no muy positivos. La cuestión está en saber si es que eran leídas para un amplio público, si se comentaban las ideas y si esto era algo sabido o no por el autor.

Pero esto que podría parecer un hecho aislado se repite, y en no pocas ocasiones se observa cómo Jovellanos sabe que esas cartas privadas, enviadas a una sola persona, multiplican la figura del receptor y por ello, si cabe, es más cuidadoso en su estilo y más reflexivo en sus opiniones, porque sabe que las noticias en ellas contenidas pueden dar lugar a nuevas y diversas opiniones, pareciendo utilizar a ese corresponsal directo como intermediario para la difusión de sus reflexiones:

Puede ser que haya dicho algo que no convenga con la historia de aquellos tiempos, o que ella desmienta algo, porque no tengo a la mano los libros que consultar; pero no por eso serán inútiles mis conjeturas porque pueden conducir al descubrimiento de alguna verdad. De todos modos, si usted creyese que pueden servir de algo a mi tío para su trabajo, sírvase usted de comunicárselas, y a mí las órdenes de su agrado.... 5 .

\footnotetext{
${ }^{4}$ Op. cit. (Bellver), 31 de marzo de 1805, de Jovellanos a Carlos González de Posada.
}

${ }^{5}$ Op. cit. (Bellver), 30 de diciembre de 1804, de Jovellanos a Carlos González Posada. 
Está firmada por Jovellanos bajo el seudónimo de Juan de Piles, para escapar de la prohibición de cartearse durante su estancia en Bellver, es un buen ejemplo para ver cómo utiliza las cartas privadas para mostrar sus ideas y a su corresponsal concreto como intermediario. Dirigida a González Posada, este comunicará las ideas que en ella mantiene Jovellanos — es la historia de los Condes de Cangas Tineo- a Francisco Martínez Marina, director de la Academia de la Historia, y que en este momento realizaba el Diccionario de Asturias. Jovellanos utiliza el ámbito de la privacidad para presentar sus ideas con una cierta repercusión social; sabedor de la repercusión social de estas ideas redactadas inicialmente para llegar a una sóla persona, no duda en enmendar sus propios errores:

Sean lo que fuere de esto, yo estuve en un error muy grosero, yo le escribí y discurrí sobre él; y ahora me delato, y le confieso a usted, y aun le pido que esta confesión se comunique al tío del sobrino, pues creo que tenga noticias de él. Pero pido también a entrambos, no sólo que me absuelvan de mi pecado, sí también que si pueden me digan de dónde me pudo venir este error ${ }^{6}$.

Ceán le sugiere la posibilidad de que sus cartas salgan a la luz, Posada sirve de intermediario de sus ideas, y a Jovellanos parece no importarle. Sin embargo, llaman la atención estas palabras con que se dirige, nuevamente, a Posada desde Bellver, a propósito de la opinión que a éste le merece la primera parte de la Descripción del Castillo de Bellver:

Si yo describiese la torre de Babel o los valles del Tempe, sería ciertamente importante cualquier alusión a nuestros sucesos; pero tratando de las paredes que nos encierran, y donde comemos y dormimos, y de los lugares que de continuo vemos y pisamos, ¿cómo sabremos ni podremos prescindir de ellos, estando malhora identificadas con nuestra existencia? Ahora, si usted, dando libertad para pensar, tiene por indiscreción escribir de nuestras cuitas, ¿diré que razón tendría si lo escrito fuese para el público? Pero yo no escribo para él ni para nadie, sino para mí, que me entretengo, para un amigo con quien trato, y para usted, que es otro amigo interpuesto entre los dos. Reflexiono pues que se trata de un escrito que no ha de presentarse a otros ojos, y que si algún día se creyere digno de la luz, ese día no excitará la crítica sino la lástima?

${ }^{6}$ Op. cit. (Bellver), 13 de septiembre de 1806, de Jovellanos a Carlos González Posada.

${ }^{7}$ Op. cit. (Bellver), 14 de noviembre (de 1806), de Jovellanos a Carlos González de Posada. 
No cabe duda que son palabras salidas de la pluma de un hombre dolido en su orgullo. Pero sobre todo en estas palabras vemos, por un lado una reflexión sobre el estilo que utiliza, y por otro como contempla la posibilidad de una publicación de sus ideas, siendo finalmente ambos asuntos superpuestos. Escribe para sí mismo de ahí la subjetividad que domina sus escritos — causa de la crítica negativa de Posada que ve en la descripción del castillo, la plasmación de sus sentimientos-, e incluso si el ámbito de recepción se multiplicase, se tradujese en una publicación de sus ideas, al primero que debería responder a su criterio estilístico, a su voluntad de estilo, idea esta que dominará en adelante los escritos que hoy denominamos ensayos. La privacidad que en este caso reivindica para su correspondencia con el amigo, tal vez sea resultado de su orgullo herido, y a la vez ya vemos como cada vez con más intensidad Jovellanos piensa en la posibilidad de que sus ideas puedan ser dadas al público.

En cualquier caso el carácter privado de su correspondencia no puede ser un impedimento para estudiar estas cartas como muestras no ya sólo de una magnífica prosa, en una interesante exposición de temas diversos, sino que es una correspondencia en la que se puede observar una y otra vez su actitud ensayística, principalmente en su preocupación por el estilo, pero también en rasgos internos de las mismas que más adelante veremos.

Son cartas enviadas a un corresponsal inicialmente único, y aunque no podemos afirmar, ni debemos, que estas cartas siempre hayan tenido más de un receptor, es evidente que en muchas ocasiones esto fue una realidad. Desconocemos el modo en que se llevaba a la amplia difusión de las ideas que nuestro ilustrado en ellas exponía, ¿la lectura ante un reducido número de amigos comunes a modo de tertulia?, ¿el comentario exegético de sus ideas? No lo sabemos, pero sí que podemos ver cómo Jovino en su momento gozaba de una gran autoridad, y que en cierto modo él lo sabía, de donde se desprende su preocupación no ya sólo por lo que dice sino por el cómo lo dice.

Jovellanos era un hombre con autoridad y cualquier idea o palabra suya tenía un interés extraordinario, principalmente aquellas que esgrimía en esta correspondencia personal y privada. Pero si se quedaba reducido al ámbito de los dos lógicos interlocutores propios del género epistolar, ¿qué sentido tenía la prohibición que sobre él cayó de escribir cartas cuando se hallaba preso en Mallorca? Era un hombre digno, comprometido, con ideas propias y, aunque eran muchos los que le admiraban, también había un gran sector que le odiaba, y temía que sus reflexiones pudiesen llegar a sectores amplios, más allá de lo estrictamente privado, de ahí esa prohibición que coartaba las extensión de sus ideas.

Y es que, como Sánchez Blanco ya ha señalado en alguna ocasión, la privacidad que se supone en este tipo de correspondencia, es una forma ideal de 
sacar a la luz ideas que de otro modo permanecerían ocultas en el mundo del propio yo:

El género epistolar muestra que el género no tiene en estos años la función de comunicarse privadamente y descubrir la faceta íntima de una persona, sino que es el conducto obligado de una opinión a la que está vedada la publicidad por razones de censura o solamente ambientales ${ }^{8}$.

Aunque yo sí que creo que en el caso del epistolario privado de Jovellanos su intimidad, su peculiar forma de ser y pensar queda patente, y en ocasiones de forma diversa según quien sea el corresponsal al que se dirige, ciertamente, la privacidad que se le supone es un magnífico modo de expresar ideas — sobre todo de carácter político- que de otro modo no podrían ver la luz sin que ello supusiera algún peligro. Privacidad más o menos restringida, exposición de ideas y estilo propio son los rasgos de estas cartas que evidencian en su estilo, una actitud ensayística.

Esta actitud ensayística se va ir manifestando en diversas cartas que, del género epistolar toman la forma — el encabezamiento y la despedida- para acoger en ellas unas la reflexión individual y personalizada sobre diferentes temas, expresadas en un ir discurriendo el pensamiento, pero siempre con un estilo propio, elaborado y necesariamente sencillo porque persigue hacerse entender, ser útil para la sociedad. Es decir, Jovellanos actúa conscientemente como ilustrado, pero toma como arma un modo de expresión que sólo mucho más tarde será bautizado como ensayo, pero que en él se manifiesta como una actitud, como muestra la constante preocupación por declarar y buscar un estilo, hoy podemos decir, ensayístico.

El estilo directo, exento de estereotipos y adornos innecesarios, que emplea en la correspondencia descubre al hombre austero y reflexivo pero tremendamente curioso y atento a lo que le rodea. Las Cartas, más que el Diario, muestran la relación de Jovellanos con otras personas (...) En ellas emerge la imagen de un sujeto, consciente de su independencia y de su perspectiva singular, (...) Revelan una inteligencia inmensa en los avatares de la política y volcada en la búsqueda de soluciones a problemas colectivos, y sólo excepcionalmente ocupado en autocomplacerse y hablar rousseaunianamente de su mundo interior. Muestran un carácter indul-

${ }^{8}$ Francisco Sánchez Blanco, La prosa del siglo xVIII. Colección Historia de la Literatura Española, Madrid, Júcar, 1992. Pág. 236. 
gente y servicial, siempre atento a las necesidades de los otros y exigente para consigo mismo9.

O lo que es lo mismo, el epistolario de Jovellanos está dominado por el subjetivismo, actualidad, compromiso, búsqueda de verdades útiles, y sobre todo por la búsqueda de un estilo, que se revela auténticamente ensayístico.

Estamos en un momento en que los autores ilustrados se sienten preocupados por el estilo que se debe imprimir a sus escritos. Dice Checa Beltrán, refiriéndose al estilo de Mayans, que éste rechazaba el estilo barroco oscuro, ambiguo, con sobreabundancia expresiva y que encontraba el ideal estilístico en el modo de hacer de tradición clásica que daba lugar a una escritura marcada por la claridad, brevedad, pureza, elegancia expresiva ${ }^{10}$. Es este un ideal estilístico que llega también a Jovellanos y que considera muy adecuada a la intención adoctrinante, de reforma que persigue.

Esa preocupación por la búsqueda de un estilo claro y preciso que se atenga tanto a su intención, llamémosla, didáctica, y que sea a la vez personal es lo que le lleva una y otra vez a reflexionar sobre su estilo. Reflexiones que aparecen en esta correspondencia y que, si bien pueden aplicarse al estilo que pretende para cualquiera de sus escritos, también es una reflexión sobre el estilo que en ese momento utiliza, el estilo al que aspira, o incluso, en ocasiones, el que recomienda. Voluntad de estilo declarada que nos permiten partir en esta caracterización del epistolario de Jovellanos como dominado por una actitud ensayística.

No hubiera dicho sobre el estilo de usted a saber de lo que usted diría sobre el mío. Expuse un sentimiento de amistad, y no de vanagloria, porque seguro que con el mío estoy riñendo a todas horas. A fuerza de regaños creo haber logrado que ande al descubierto, pero no que se adorne con atavíos muy esenciales, y sin los cuales le encuentro muchas veces, porque dice que no los halle a mano al tiempo de vestirse, aun cuando se viste de gala. Hablo de la precisión y el acumen. Sin la primera su despejo se ve con gusto, pero sin interés: sin el segundo puede contentarse el juicio, pero no la imaginación. Una frase perspicua, en que nada sobre ni falte, ¿̨cuándo se logra? Y si alguna vez, que sea además aguda y agraciada ¿̨cuándo? Contentémonos, pues, con lo que Dios nos ha dado, en tiempos en que el estilo se va corrompiendo por todas las provincias de la república

\footnotetext{
${ }^{9}$ Ibid. Pág. 236.

${ }^{10}$ Vid. José Checa Beltrán, «Teoría Literaria», en El reformismo borbónico. Madrid, C.S.I.C., 1996. Pág. 493.
} 
literaria, así como las costumbres, y en un país donde el buen modelo aún está por venir ${ }^{11}$.

Como podemos comprobar en estas palabras de Jovellanos, la cuestión del estilo era un tema que le obsesionaba. Es esta una reflexión sobre el estilo en general, cuestión debatida en el momento por muchos otros autores, dado que se veía una decadencia, una corrupción del mismo, marcado por un barroquismo extremo. Pero en estas palabras lo que Jovellanos evidencia es una auténtica preocupación por su propio estilo con el que siempre está «riñendo». Su preocupación fundamental estriba en el modo de combinar ars e ingenium, cómo lograr enseñar deleitando, sin aburrir o complicar las ideas, logrando el término justo. La solución, como repite una y otra vez hasta la saciedad en esta correspondencia, la encuentra en la búsqueda de un estilo personal.

En esta continuada reflexión sobre el estilo, en la que aboga por un estilo personal, podemos ir viendo como se va declarando su actitud estilística, una voluntad de estilo en la que se puede ver una forma de actuar y concebir los escritos que, sin salirse de los márgenes establecidos de su tiempo, son auténticas declaraciones ensayísticas. Reflexión individual sobre su modo de escritura, pero mostrando tal seguridad a la hora de considerar que el buen estilo es aquel que se forma cada uno, que huye de la imitación servil de grandes modelos establecidos que empañan, incluso ocultan, el verdadero sentir del autor, que en más de una ocasión lo aconseja a los demás.

Utiliza el espacio que su correspondencia, más o menos, privada le otorga para reflexionar sobre el estilo y aconsejar a los demás que impriman su personal voluntad estilística a los escritos de acuerdo con el tema e intención que en ellos dominen. Son consejos que lanza, y se aplica, para abordar diversos escritos. No obstante, me parecen interesantes un par de reflexiones que afectan directamente al estilo que se utiliza en el género epistolar y, concretamente en cartas de carácter privado.

Mucho me ha gustado el estilo de esta última carta de usted, que (aunque sin desdecir del de las otras) tiene un particular desahogo, como si la prisa de las fiestas empujase y diese más fácil salida a las ideas, y más fluidez a las frases. Puede ser cierto en las obras de elocuencia, en que tanta parte tiene la imaginación; pero no, voto a tal, en el de al correspondencia epistolar, en que a la mayor madurez y firmeza de las ideas se junta la mayor facilidad que da el hábito de expresarlas.

${ }^{11}$ Op. cit. (Bellver), 28 de agosto de 1805, de Jovellanos a Carlos González de Posada. 
¡Cuánto más cartas no estudiadas y familiares y amistosas en que el estilo sale de la abundancia de corazón! ${ }^{12}$.

Fluidez de ideas, frases ágiles y estilo que sale del sentimiento, es lo que Jovellanos elogia en su buen amigo Posada. Pero ¿̨dónde encuentra precisamente ese estilo personal, subjetivo, verdadero? En la correspondencia de carácter privado, íntimo y amistoso en las que el estilo sale de uno mismo sin que esto signifique descuido a la hora de abordar el texto, sino por el contrario veracidad. La correspondencia de Jovellanos podemos afirmar sin riesgo a equivocarnos, que goza de todos estos rasgos que tan elogiosamente alaba en su amigo, porque es en ella, incluso mejor que en sus Diarios, donde vemos el verdadero yo de don Gaspar, su forma de discurrir y plantear las ideas de forma directa, ágil, sencilla pero elaborada; actitud ensayística y voluntad de estilo.

En otra carta más adelante volverá a insistir en esa búsqueda del estilo propio en las cartas, y particularmente, en esa necesidad de escribir según dicta la razón y el sentimiento de cada uno, sin pretender seguir el de nadie, porque sólo de este modo se logrará eficacia en la expresión, pero sobre todo se actuará directamente sobre el receptor:

No sienta usted haber escrito sus cartas de prisa, porque si no han sido tan filosóficas como las de Cicerón, tan graciosas y discretas como las de Plinio el Mozo, ni tan eruditas como las del que usted llama mi ángel, a los menos, sobre tener algo de todo esto, se parecerán también a las de la buena Sevigné por la fluidez de estilo que, a veces sereno, a veces rápido, y tal vez desenvuelto, aunque con decencia y gracia, corre siempre natural y sin violencia, pareciendo que sale más del corazón que de la pluma! ${ }^{13}$.

Fluidez, naturalidad, desenvoltura son los rasgos que destaca para lograr un buen estilo personal, proponiendo como ejemplo, que no como autoridad, el estilo de madame de Sevigné que escribió unas cartas a su hija en un estilo ágil, sencillo y elegante, cartas movidas todas ellas por el sentimiento. Pero sobre todo lo que Jovellanos rechaza es imitar decididamente el estilo de, no cabe duda, excelentes autores porque el tono que en ellos se respira como natural y espontáneo, en quien imita suena a vacío, hueco, falso. El uso de un estilo personal y cuidado es un método eficaz para llegar al lector, atraerlo y hacerle compartir las ideas expuestas, participando del sentimiento del que las emite. Y si

${ }^{12}$ Op. cit. (Bellver), 15 de marzo de 1807, de Jovellanos a Carlos González de Posada.

${ }^{13}$ Op. cit. (Bellver), 24 de octubre de 1806, de Jovellanos a Carlos González de Posada. 
este estilo personal es necesario en cualquier tipo de escritos, lógicamente, Jovellanos considera más necesario aplicarlo a un tipo de escrito, como la correspondencia privada, que está presidida voluntariamente por el yo que escribe.

No volvamos, pues, a dar sobre el estilo, que cada uno tiene el suyo, y debe estar contento con él. Hay en todo una fisonomía individual, que no se puede desfigurar sin maltratarlos. En obras de composición pase el cuidado de repulirlas; in epistolis, decía Policiano, negligentia est ipsa pro cultu. Escribamos, pues, como él escribía, ad usum praesentem dum taxat, oblatis argumentum, non quastis ${ }^{14}$.

Hasta tal punto tiene confianza don Gaspar en ese estilo personal, en esa voluntad estilística, que, cuando se lo piden o lo considera necesario, habla sobre él con sus corresponsales, mostrando la necesidad de trabajarlo y perfeccionarlo. Una reflexión sobre el estilo en la que podremos apuntar rasgos propios de una actitud ensayística, y en la que insiste en la necesidad de olvidarse de modelos establecidos a los que seguir insistentemente. Veamos algún ejemplo.

Una de las mejores reflexiones que encontramos sobre el estilo en Jovellanos, se encuentra en una carta que éste dirige a Vargas Ponce. El objeto de la misma es la obra que Vargas Ponce había presentado al concurso de la Academia, La Declamación contra los abusos introducidos en el castellano. Jovellanos la analiza y considera que su fracaso se debe a, en primer lugar, la total ausencia de un estilo personal, y en segundo lugar, el no haber elegido un estilo didáctico más acorde con la intención general de la obra, aspecto este del didactismo que veremos más adelante. El tono que utiliza Jovellanos es directo y duro, pero sobre todo interesante al insistir en el horror que produce ver el esfuerzo mimético que oscurece las ideas e intenciones del autor:

(...) sobre todo, ¿Cómo es que usted no ha fijado su estilo, no se ha formado un estilo propio? Yo no puedo observarlo sin dolor, pero ello es cierto; cada obra que sale de la pluma de usted parece de otra. (...) ¿Cómo es, pues, que usted, tan fecundo, tan fácil, tan igual cuando habla, cuando escribe, cuando discurre con sus amigos, no es igualmente fácil, igual y fecundo cuando compone? ¿Me encargaré de la respuesta? Es fácil y breve. Usted es uno cuando habla y escribe, y otro cuando compone; allí es usted Vargas, aquí otro que huye de Vargas, o quiere encaramarse sobre él. En una palabra, usted no se ha formado un estilo propio, sólo porque se ha empeñado en apropiarse el ajeno.

Amigo mío, la naturaleza ha dado a cada hombre su estilo, como una fisonomía y un carácter. El hombre puede cultivarle, pulirle, mejorarle, pero cambiarle no.

${ }^{14}$ Op. cit. (Bellver), 9 de mayo de 1806, de Jovellanos a Carlos González de Posada. 
(...) Restitúyase usted a sí mismo: escriba como habla, componga como escribe, y todo está hecho. Nada, nada le faltará entonces. Pues que concibe bien necesariamente escribirá bien; y si, como dijo Horacio, scribendi recte sapere est et princium et finis, sabiendo y entendiendo bien las materias en que escribe, esté seguro que escribirá bien, siempre que no se empeñe en escribir mejor ${ }^{15}$.

Más claro no puede ser el ilustrado. La búsqueda del estilo personal, no está reñido con el hecho de pulirlo, eso sí sin querer mejorarlo porque sí, imitando y, sobre todo, abarcando más de lo que las propias limitaciones que cada uno tiene y debe conocer le dictan. Además en estas palabras de Jovellanos vemos una idea enormemente interesante en la que se manifiesta su no declarada actitud ensayística: escribir como se habla, y escribir como se discurre. Precisamente este es uno de los rasgos definitorios del género ensayístico: la naturalidad en la escritura viene precisamente dada porque en el ensayo lo que se está recreando es la forma de pensar, de discurrir el autor, no exento de divagaciones y sobre todo, pleno de subjetivismo y personalidad, aunque, tengámoslo presente, este es un artificio que hay que saber manejar para que ese libre discurrir de ideas aparenten un caos lógicamente ordenado.

Voluntad estilística en la que debe estar presente la intención que se persigue con cada escrito, y una de las intenciones fundamentales que se descubren, no ya sólo en Jovellanos, sino en prácticamente todos los autores del siglo ilustrado, es la de enseñar, se puede descubrir un cierto afán didáctico.

Esa intención didáctica que se observa en muchos escritos del momento, ha originado toda una prosa de ideas en la que Pedro Álvarez Miranda ha visto una forma de expresión muy cercana a la que hoy se califica de ensayo ${ }^{16}$. Ciertamente estamos ante una prosa en la que se puede ver la mentalidad ilustrada que persigue la utilidad, el proporcionar ideas y pautas que conduzcan a reformas de diverso índole, una prosa con la que se pretende dar difusión a las ideas ilustradas y el mejor modo que encuentra es este que señala, con total certeza, el asturiano: una prosa personal, clara en lo que él denomina estilo didáctico, y al que le otorga los siguientes rasgos:

Pues yo deseo que mis matemáticos contraigan los principios y el uso de un buen estilo didáctico, para que consultando, informando, escribiendo pueda dar orden y claridad a sus ideas, y de seguro el que tenga uno y otro, escribirá con el tiempo con pureza y precisión (...).

\footnotetext{
${ }^{15}$ Op. cit. Gijón, 11 de diciembre de 1799, de Jovellanos a José de Vargas Ponce.

16 Vid. Pedro Álvarez de Miranda, «Para la historia de la palabra ensayo: algunos datos del siglo XviII", en El ensayo. Compás de Letras, n 5, págs. 157-187, y, especialmente, «El ensayo» en Historia literaria de España en el siglo XVIII, ed. Francisco Aguilar Piñal, Madrid, Editorial Trotta, C.S.I.C., 1996, págs. 285-325.
} 
El método sencillo, acomodado al objeto: pocos preceptos, ejemplos muchos; poco fiado a la memoria, mucho a la explicación paciente y constante, hasta que se sepa haberse entendido cuanto se propone ${ }^{17}$.

No hay que olvidar la sencillez que requiere el estilo didáctico... sea claro y preciso $^{18}$.

El deseo de hacerse entender es algo que parece consustancial al estilo e intención didáctica, pero donde reside la actitud ensayística es en el cómo lograrlo. Del ensayista se exige un conocimiento del tema que está tratando, y una exposición clara y ordenada que refleje su propio modo de pensar; el ensayista se alejará de la cita erudita y se ceñirá a su experiencia y reflexión, para explicar el asunto que le interesa sirviéndose de ejemplos cercanos, con la única intención de hacerse entender. Todo ello lo conseguirá procurando fijarse en el modo en que aborda el escrito, buscando la precisión y claridad, huyendo de la erudición y la falsedad.

Estos rasgos que se observan como propios del género ensayístico, ¿acaso no son los mismos que aconseja el propio Jovellanos, y que él mismo utiliza? Nuevamente estamos ante una declaración ensayística de nuestro autor, que habla de estilo didáctico pero que ve en esta forma de expresión el método más eficaz de lograr las propuestas ilustradas. En sus cartas, como más adelante veremos, se hace eco de este estilo, y en una continuada necesidad de declararse sobre el modo en que escribe, veremos ir perfilándose los rasgos del ensayo.

Veíamos más arriba la crítica que lanzaba a Vargas Ponce, al que acusaba de no saber hacer uso de un estilo coloquial y propio. Pero otro error que le achaca a su obra, para don Gaspar tan importante como el anterior, es el no haber elegido el estilo didáctico más conforme a las intenciones y materia que su obra requería:

¿Cómo es que usted eligió el estilo oratorio para un discurso que sólo podía admitir el didáctico? Me dirá que la Academia no le señaló esto entre las condiciones del problema, y así es verdad; pero la Academia le deseó en tanto grado, que eligió este asunto de discusión para llamar la atención del público al estilo didáctico que requería, y desde luego así se le propuso. Se le propuso por se este estilo el que debía cultivar con preferencia, como el de más frecuente uso, el más propio par tratar las materias literarias, el más necesario en una nación donde

${ }^{17}$ Op. cit. (Gijón), 7 de mayo de 1800, de Jovellanos a Carlos González Posada.

${ }^{18}$ Op. cit. (Bellver) 9 de noviembre de 1805, de Jovellanos a Carlos González Posada. 
hay que demostrar hasta las primeras verdades, y en un país donde la oratoria apenas tiene más teatro que los púlpitos. Se le propuso como aquel que requieren las disertaciones, memorias, informes, consultas, apologías y cualquiera exposición de nuevas ideas y proyectos. Se le propuso, en fin, porque sirviendo diariamente a la política, la legislación, la economía, la ciencia, la moral, y aun la literatura, no hay país ni nación a quien no le hagan más falta buenos escritores didácticos que grandes oradores, y donde no sea más provechoso el estilo de los Diálogos de Platón y de los académicos de Tulio, que el de la Miloniana del mismo Tulio, o el de la Filípicas de Demóstenes ${ }^{19}$.

Como vemos, Jovellanos ve en este estilo didáctico el más adecuado para tratar temas que pueden generar cierta polémica, el ensayo toma temas actuales con los que polemizar en el sentido de hacer reflexionar, y como escrito de estructura abierta y flexiva generar otras opiniones. Es el que se utiliza en disertaciones, memorias, informes, consultas, nombres todos estos bajo los que se oculta la forma del ensayo en el siglo XVIII y que nuestro autor cultiva con gran eficacia. Es el estilo que se utiliza para tratar de las más diversas disciplinas, del mismo modo que ocurre con el ensayo, porque es el necesario para el bien de un país que se pretende reformar, en el que se pretende un conocimiento más amplio de cuestiones diversas, y sea capaz de desterrar errores comunes.

Sus reflexiones acerca del estilo más adecuado a las intenciones de un autor que pretende hacerse entender mostrando ideas útiles, la actitud que más se adecua es la propiamente ensayística, hable nuestro ilustrado de estilo personal, hable de estilo didáctico. Cabría preguntarse si el gijonés sólo las aconseja o realmente las lleva a la práctica. Recordemos que consideraba que este estilo personal y didáctico tenía en la correspondencia un buen lugar de expresión. Como buen ilustrado, como veremos, Jovellanos no se queda en la reflexión y el consejo, sino que él mismo se lo aplicará, asistiendo en sus cartas a la plasmación de todos estos ideales estilísticos, observando no sólo su actitud como ensayista, sino un auténtico despliegue de los rasgos que se señalan para el ensayo.

Ahora bien, el problema no es descubrir la influencia de la lectura de una obra cualquiera en la génesis de los ensayos de Montaigne, sino estudiar la tradición literaria del ensayo a partir de sus características genéricas más sobresalientes, como su relativa brevedad, la presentación personalizada del conocimiento o la frag-

${ }^{19}$ Op. cit. Gijón, 11 de diciembre de 1799, de Jovellanos a José de Vargas Ponce. 
mentación en las distintas partes que componen los ensayos. Todas estas características se deben abstraer con independencia del estilo peculiar de cada ensayista que puede ser diverso ${ }^{20}$.

Siguiendo las indicaciones de Mainer, podemos ver de qué modo se va configurando la historia, la forma del ensayo en momentos en que no existe una conciencia genérica del mismo. Partir de los rasgos más sobresalientes del género para observar de qué modo se dan en esta correspondencia privada de Jovellanos, movida por un constante deseo de diálogo, sobre temas de interés general —al menos para su grupo — en lo que él llama estilo didáctico, y que nosotros podemos considerar estilo ensayístico.

El ensayo es fruto deliberado del ensayista. Es un tipo de escrito en el que el ensayista, su personalidad acapara la totalidad del mismo. Desde el momento mismo en que elige el tema que él considera digno de ser presentado al lector para que este reflexiones, la pluma del ensayista va dejando huella de su forma de pensar, de su verdadero sentir, un yo que se reafirma en ese estilo peculiar y único de cada ensayista. Es por tanto un tipo de escrito dominado por la personalidad del autor, lo que ha llevado a considerar el ensayo como un escrito enternamente subjetivo en el que, no obstante, la opinión del autor ofrece la pretensión de convertirse en la compartida por el común de sus lectores.

García Gual, en un espléndido artículo, presenta una caracterización del ensayo mostrando como sus rasgos derivan, fundamentalmente, de ese subjetivismo, de la propia personalidad distinta y arrolladora del ensayista.

Frente al afán enciclopédico y un cierto saber mundano general, el ensayista busca un acento personal y subjetivo, y, dentro de la prosa de tono medio que es la habitual, una voz propia en el coloquio abierto sobre temas que interesan a muchos. Su magisterio no está avalado por títulos ni saberes especializados, sino por su inteligencia, su agudeza y su habilidad expresiva, es decir, por su personalidad literaria. No está mal que el ensayista posea un sólido bagaje cultural o una buena formación filosófica, pero lo que le da valor como tal es su buen estilo. Su enfoque puede ser parcial, informal, subjetivo — como hemos dicho ya repetidamente, pero ahí está justamente su atractivo. Debe ser ameno, interesante (más por su modo de exponer que por los temas tratados, pero también por esa selección personal de los mismos), y sugestivo, de ahí la gran modernidad del ensayo ${ }^{21}$.

\footnotetext{
${ }^{20}$ Vid. José Carlos Mainer, «Introducción», a Jesús Gómez (ed.), El ensayo español. I. Los orígenes: siglos XV a XVII, Barcelona, Crítica, 1996, pág. 37.

${ }^{21}$ Vid. Carlos García Gual, «Algunas consideraciones sobre los orígenes helénicos o helenísticos del ensayo como forma literaria» en El ensayo... pág. 106-107.
} 
Subjetivismo es el término con que se parece definir el ensayo, el rasgo al partir del cuál surgen el resto de características del mismo. Escrito dominado por la personalidad del ensayista desde la elección del tema hasta el modo de presentarlo. Los caracteres que imprime este subjetivismo al ensayo son: la prosa elaborada, pero de fácil compresión, en un tono coloquial. Del ensayista no se pide erudición sino conocimiento y sobre todo saber mostrar sus ideas, sin que la parcialidad, la subjetividad que surge de este tipo de escritos en las opiniones expuestas, suponga un rasgo negativo sino todo lo contrario. El tema presentado de forma interesante y amena, con ideas que se pretende sean de interés general, es el que da a este tipo de escritos una constante modernidad.

Francisco Cienfuegos ha dicho de Jovellanos que es un hombre del XVIII con mentalidad del xx. Está evidenciando en esta opinión su constante modernidad y atracción de sus ideas cuando han transcurrido más de dos siglos desde que las difundió. Sus cartas, son un ejemplo del interés que despierta el ilustrado, la causa de este atractivo, sin poner en duda que se revelan como interesante documento histórico, es el modo en que se han concebido, dominadas por la personalidad de su autor, por el estilo que utiliza y los temas que trata. En definitiva, por haberles imprimido un tono ensayístico de forma totalmente consciente y voluntaria. Elige los temas que interesan en el momento y los trata según su particular forma de pensar con la intención de hacerse entender y llegar a un número más o menos reducido de personas en los que sabe que puede influir (ya hemos comentado como la privacidad de esta correspondencia no obstaculiza la difusión de sus ideas).

El género epistolar ofrece un marco de incomparable idoneidad para que en ella tomen forma los rasgos propios del ensayo: desde el dominio absoluto y justificado del yo que muestra su reflexión personal sobre los más variados asuntos, hasta la brevedad que permite mostrar sin agotar, y que hace posible el continuar un diálogo mantenido en diferentes momentos. Son estos rasgos del ensayo los que se pueden ver en sus cartas. Jovellanos reflexiona sobre los temas de que trata y, sabiendo cuáles son los límites propios de la carta, da forma a su pensamiento en un continuado reflexionar propio, e interesante diálogo directo con su receptor. Es el modo de actuar propio del ilustrado como firme antecesor de los actuales ensayistas.

Apenas hay tiempo para poner dos renglones, ¿y quiere materia para una disertación? La censura de las fiestas de toros da para mucha meditación y tiempo, porque si bien la causa es ventajosa, los argumentos con que puede y debe sostenerse son muchos y varios, y serán más concluyentes cuanto más de propósito, más clara y ordenadamente se expusieren. Diré, sin embargo, lo que me ocurre 
en el instante, porque no tengo ni tiempo ni cabeza para más, bien seguro de que cualquiera cosa que diga recibirá mucho valor de la fogosa y elocuente pluma de usted $^{22}$.

Por disertación en aquel momento se entendía un «discurso en que se proponen las razones que hay a favor de alguna opinión, y se impugnan las contrarias» ${ }^{23}$. Y entre las acepciones de discurso se encuentra la de tratado. Esto nos hace pensar que Jovellanos establece una línea divisoria entre el discurso y la carta, observando que en esta última puede dar a la luz sus ideas sin agotarlas, de forma esquemática pero ordenada, y lo que me parece aún de mayor interés, observa como realidad el hecho de que el receptor las utilice en su propia reflexión siendo el germen de un continuado diálogo. Son ideas que dice salidas de forma inmediata, pero a nadie se oculta que Jovellanos no veía con agrado la llamada fiesta nacional, lo que nos hace pensar en un planteamiento breve pero nunca irreflexivo.

La brevedad es un rasgo propio del ensayo. Recordemos que este es un carácter que califica al género por oposición al tratado, en lo que puede parecer una acusación un tanto peyorativa. Jovellanos utiliza de forma consciente las limitaciones que una carta imponen, no porque piense como un ensayista, sino porque lo que busca es mostrar su pensamiento, dar su opinión sobre los temas que le interesan a él o a sus contertulios epistolares. No pretende mostrar su erudición, ni verdades universales, sino su peculiar punto de vista sin divagar en exceso, por lo que elige el esquema de la carta, pero necesita justificar esa elección, justificación que le hacen caer en tópicos de falsa modestia, la prisa que le impide abordar una obra más amplia, apoyándose siempre en que la carta es lo que es y no da espacio para más.

Como tú no puedes ignorar que una carta ofrece poco campo para tratar tan grave asunto, cual es formar una Constitución, no me apresuré a satisfacer el deseo que tiempo ha me manifestate de saber mis ideas acerca de este punto ${ }^{24}$.

Si hubiese tenido más tiempo y tranquilidad, la carta preliminar hubiera sido una disertación sobre la poesía en general, y en ella se hubieran discutido algunos puntos curiosos que no han ejercitado hasta ahora la pluma de los eruditos. Sobre el verso blanco hubiera ordenado cuanto yo pienso en favor de su uso, y en fin hubiera dicho cuanto sé y cuanto pienso sobre esta materia. Pero sobre haberme

\footnotetext{
${ }^{22}$ Op. cit. Gijón, (13 de julio de 1792), de Jovellanos a José de Vargas Ponce.

${ }^{23}$ Vid. Diccionario de la Lengua Castellana, compuesto por la Real Academia Española, Vda. de Joaquín Ibarra, Madrid, 1803 (4⿳亠丷厂巾 edición).

${ }^{24}$ Op. cit. (Gijón, agosto de 1811), de Jovellanos a Alonso Cañedo y Vigil.
} 
sorprendido el conductor, dificulto que hasta dejar el oficio de Alcalde hubiera podido hallar el tiempo necesario para el desempeño de un objeto que requería algún estudio y mucha meditación ${ }^{25}$.

Después de haber leído primera y segunda vez la Historia, voy a decirle sencillamente el juicio que he formado acerca de su mérito, exponiendo con el orden que puede permitir una carta, mi dictamen sobre cada una de sus partes y deduciendo de aquí la utilidad o perjuicio que puede traer su publicación, tanto a usted como al público ${ }^{26}$.

De todos es conocido que Jovellanos era un hombre con multitud de ocupaciones que le impedían dedicarse por completo a quehaceres concretos. La historia, la poesía, la política son sólo alguno de los temas que le interesaban $y$, aunque son temas que ocuparon buena parte de sus informes y discursos (otras fórmulas en las que se puede reconocer el ensayo), nunca intentó elaborar tratados. Sin embargo, reflexiona y lee sobre todas estas cuestiones, y muchas otras, y elige la brevedad de la carta para mostrar esas opiniones subjetivas que le sugieren. ¿Por qué?

Jovellanos no pretende mostrar su erudición sino que, como hombre de su tiempo lo que intenta es hacer que los demás participen de sus ideas, las consideren, las tomen y reflexionen para aceptarlas o para criticarlas. Participa con sus cartas en una difusión del conocimiento sobre la más amplia variedad temática en un continuado diálogo en el que los temas se multiplican, se toman y se retoman.

Paréceme a mí por la susodicha carta que no fue vana sospecha mía, antes concebida y ahora confirmada, de que usted se había hecho un si es o no es artolaista, y pido a Dios que me engañe, o que si no, le saque a usted de semejante tentación ${ }^{27}$.

Se ha dicho que el ensayo es un escrito capaz de abordar una amplia gama de temas sin necesidad de mostrar erudición, aunque sí conocimiento, temas que responden a la actualidad, al interés, capaces de generar polémicas, de hacer que el lector considere las reflexiones allí expuestas y logre retomarlas para aceptarlas o debatirlas. La temática que Jovellanos aborda aquí es amplia y variada. Responde a los intereses generales del momento — derecho, política, enseñanza-

\footnotetext{
${ }^{25}$ Op. cit. (Madrid, abril de 1780), de Jovellanos a su hermano Francisco de Paula.

${ }^{26}$ Op. cit. (1793?) de Jovellanos a Bernardo Alonso de Ribero y Larrea.

${ }^{27}$ Op. cit. (Bellver, a. a 31 de enero de 1805), de Jovellanos a Carlos González Posada.
} 
, a los suyos propios, aunque compartidos con sus interlocutores — cuestiones asturianas, filológicas-, pero siempre pensando que esos temas son necesarios y que de sus ideas se puede sacar alguna utilidad.

Para mí, la instrucción es la fuente de toda prosperidad social, y a la demostración de esta verdad están consagrados mi celo, mis luces, mi tiempo y mi existencia. Sé que éste debe ser nuestro grande, nuestro primer cuidado, nuestro uno necesario ${ }^{28}$.

Si este es el motivo fundamental que le mueven muchos de sus escritos, y muchas de estas cartas en las que expone lo que opina, conoce, intuye, moviéndonos en el pensamiento de un hombre ilustrado, el mejor medio para lograr estos fines, es adentrarnos nuevamente en la cuestión del estilo didáctico y la utilidad de los juicios emitidos, que nos permiten ver un Jovellanos que participa decididamente del modo de hacer y pensar ilustrado, llevando a sus cartas esas ideas, reflexiones breves pero concisas, y sobre todo útiles, que darán lugar a nuevas reflexiones, en una clara actitud ensayística.

Excelentísimo Señor: en las materias que tienen relación con la pública utilidad, es lícito a cualquier ciudadano dirigir sus reflexiones al Gobierno y sugerirle las buenas máximas que la meditación y el estudio le hubiesen inspirado. Esta verdad me hace toma la pluma y me autoriza a distraer por un rato la atención de vuecelencia ${ }^{29}$.

Una y otra vez hemos visto que en estas cartas lo que se manifiesta de principio a fin es el yo del autor. La fórmula autobiográfica propia de una actitud ensayística es la que adopta don Gaspar, porque lo que hace es exponer su pensamiento. En alguna ocasión disculpa la falta de orden que se puede derivar de intentar mostrar en tan poco espacio sus reflexiones. Sin embargo, a poco que vayamos avanzando en ellas, observaremos que todo está perfectamente medido, ordenado; toda la carta se estructura a modo de pensamiento, en el que una idea lleva a otra y, en ocasiones, se pierde para sólo más tarde volver a recuperarla.

Digresión, propia de una actitud ensayística, que refleja el modo de pensar de don Gaspar. Pero si bien el pensamiento es caótico por definición, en esta correspondencia, de igual modo que en el ensayo actual, se da un orden a

${ }^{28}$ Op. cit. (Gijón, 23 de julio de 1800), de Jovellanos a Rafael Floranes.

${ }^{29}$ Op. cit. (Madrid, noviembre de 1787), de Jovellanos al Conde de Floridablanca. 
las ideas, el que subjetivamente considera más adecuado a las intenciones del autor; Jovellanos marca ese orden, siente la necesidad de guiar el pensamiento del otro sin ocultar los pasos que va dando, como una idea sugiere otra idea.

Después de escrita mi anterior, me parece debo añadir a lo dicho en ella algo de lo que me ha ocurrido después, allá va, valga lo que valiere ${ }^{30}$.

Y ahora, para que no falte en nuestra correspondencia alguna cosa de nuestro queridito dialecto ${ }^{31}$.

Todavía en esta carta hablaré de la nueva estampa, porque usted en la del 28 me da mucho motivo para ello. El asunto es digno por su piadoso objeto y la discusión agradable, porque es de las artes que ambos amamos $(\ldots)^{32}$.

El carácter digresivo es evidente en esta correspondencia, hasta tal punto que en muchas ocasiones los temas sobre los que se divaga ocuparán varias y diferentes cartas. El abandono del tema o la idea, para más adelante volver sobre ella viene motivada por otro rasgo característico de los ensayistas, el carácter dialógico.

Si pretende ser útil, llegar al lector, hacerse entender, es lógico que escoja un estilo claro y preciso, alejado de la oscuridad de una divagación erudita y compleja, y mostrando su cercanía al lector. Es una correspondencia de carácter privado, y si por una parte se observa que este género parece obligarle a utilizar siempre la primera persona, son cartas, diálogos que mantiene con personas a las que conoce, divagaciones en torno a cuestiones concretas que le lanzan. En definitiva, Jovellanos conoce a su interlocutor, sus intereses y limitaciones, pero a pesar de este carácter privado, como ya hemos dicho, se sabe portador de ideas que pueden divulgarse. Continuamente interpela a su receptor, sea por su nombre, sea por su apodo, sea por un genérico tú. Pero siempre lo hace en un tono directo, entre iguales, con un constante empeño por hacerse entender, de donde se desprende ese manejo diferente de la cita, que veremos más abajo.

El estilo sencillo y personal, su ideal, y el increpar directamente a su interlocutor de igual a igual son muestras de ese tono coloquial, de esa búsqueda

${ }^{30}$ Op. cit. (Bellver), 21 de julio de 1804, de Jovellanos a Carlos González de Posada.

${ }^{31}$ Op. cit. (Bellver), 26 de octubre de 1804, de Jovellanos a Carlos González de Posada.

32 Op. cit. (Bellver), 31 de marzo de 1805, de Jovellanos a Carlos González de Posada. Esta carta nos remite a una de fecha anterior en la que tratan del mismo asunto, la estampa del Cristo de Candás, mostrando su carácter digresivo y recurrente. 
de diálogo de la actitud ensayística. Son frecuentes las ocasiones en que el asturiano utiliza expresiones que nos indican una concepción oral del discurso, (os hablo, os digo...). Con ello pretende mantener atento a su lector en un diálogo abierto. La carta, como el ensayo, es aquí concebido como un escrito abierto que da lugar a diversas opiniones que se cruzan; Jovellanos pretende no sólo mostrar sus ideas, sino que estas sean comentadas por los otros y den lugar a nuevas cartas, como efectivamente podemos ver, donde el tema se retoma, e incluso se plantea según perspectivas nuevas, novedad motivada por las reflexiones del otro y otros que participan de ese diálogo cruzado.

Mi muy estimado amigo y señor: porque quisiera escribir a usted muy despacio, he ido prolongando de un día en otro la contestación a su favorecida del 10; pero el tiempo tiene una condición tan resbaladiza, que se nos va entre las manos sin sentirlo y sin que alcance la mitad de nuestros propósitos. Quiero, por tanto, aprovechar estos instantes libres, aunque breves, para hablar con usted algo de lo que mucho deseo $0^{33}$.

Al fin, como crítico (pues usted supone, y no sin razón, que será grande el número de los que examinen como tales la estampa) diré también lo que me ocurre, si quiera para hablar con usted algunos reparo que tal vez espera y que no puede desconocer ${ }^{34}$.

Dado que es un diálogo entre iguales en el que Jovellanos no pretende mostrarse como un erudito en las materias de las que trata, por lo que ha escogido las limitaciones de la carta, sino su particular opinión, es lógico que las citas que en sus cartas aparecen no son tomadas sólo y exclusivamente como autoridades irrefutables. En Jovellanos asistimos a una nueva concepción de la cita, con la que explica sin ponerse en un plano superior sino desde la igualdad que se supone en ese diálogo mantenido.

¡Soberbia pretensión, dirá usted! Tal lo creo yo. Pero ¿qué aventuro a proponerle el juicio de usted, que como buen hurón de noticias recónditas podrá tan fácilmente confirmarlo o desvanecerlo?

(...) lo demás queda a cargo de usted. Y pues me consta que tiene extractadas noticias del pleito de los Quiñones, creo que estará en el camino real para completar cuanto falta a esta averiguación.

\footnotetext{
${ }^{33}$ Op. cit. Gijón, 31 de diciembre de 1796, de Jovellanos a Francisco de Paula Caveda y Solares.

${ }^{34}$ Op. cit. (Bellver), nonis martiis (7 de marzo), A.R.S. M.DCCCV, de Jovellanos a Carlos González de Posada.
} 
Puede ser que haya dicho algo que no convenga con la historia de aquellos tiempos, o que ella desmienta, porque no tengo a mano los libros que consultar; pero no por eso serían inútiles mis conjeturas, porque pueden conducir al descubrimiento de alguna verdad. De todos modos, si usted cree que pueden servir de algo a mi tío para su trabajo, sírvase ustede comunicárseles ${ }^{35}$.

Recordemos que en este momento la experiencia, la reflexión a que conlleva un estudio de cualquier asunto, son más importantes que lo que la tradición sustenta como única verdad. En este sentido las autoridades, las citas, caen de ese pedestal que durante tanto tiempo las había sostenido como verdades irrefutables, siendo sustituidas por lo que la experiencia y la razón dicta como auténtico.

Pero si de una parte es cierto que la verdad, cualquiera que ella sea, no puede dejar de ser provechosa, de otra no lo es menos que los que quieren revolver y trastornar no buscan su apoyo en la autoridad, sino en el raciocinio; no en los ejemplos de la antigüedad, que menosprecian, sino en los sistemas nuevos que ellos mismos forjaron y en los medios de corrupción y de fuerza que han hallado en la ignorancia y la ilusión de los pueblos; y esto es tan cierto, que acaso para librar a las sociedades de semejantes errores y calamidades no habrá un camino más seguro que el ilustrarlos, pues no con la ignorancia, sino con la verdadera ilustración se puede hacer la guerra a las opiniones peligrosas o destruir su influjo ${ }^{36}$.

Para don Gaspar la reflexión personal, el anotar datos sobre los que sustentar los juicios que se emiten adquieren un valor indescriptible. De este modo la experiencia se muestra como argumento de indiscutible valor para afirmar aquello que se intenta demostrar.

No significa esto que la cita desaparezca — ya hemos visto casos de citaspero sí el tono con que se utilizan. La cita de oídas, recordada vagamente, marcada por el tono personal de la experiencia propia o compartida, el ejemplo, aparecerán constantemente en un tipo de escrito que pretende sea ameno y didáctico.

Acuérdome de haber leído en Sevilla un folleto de Moratín el Padre (...) pero no he dejado en mi memoria rastro alguno de noticia o especie recomendándole para el caso. Búsquelo usted no obstante, porque defendiendo como recuerdo, la causa contraria, podría ser útil tener a la vista sus argumentos ${ }^{37}$.

\footnotetext{
${ }^{35}$ Op. cit. (Bellver), 30 de diciembre de 1804, de Jovellanos a Carlos González de Posada.

${ }^{36}$ Op. cit. Gijón, diciembre de 1800, de Jovellanos a Juan Francisco Masdeu.

${ }^{37}$ Op. cit. Gijón, (13 de julio de 1792), de Jovellanos a José de Vargas Ponce.
} 
Tenía yo en mis mamotretos noticia de que este famoso sabio había sido conde de Cangas y Tineo, y con ella algunas otras especies relativas a este señorío; pero el tiempo las había borrado, como otras muchas de mi cabeza. Y pues que ahora hallo en Pellicer noticias más cumplidas de este conde, vayan aquí las que pueden llenar aquella falta ${ }^{38}$.

Como podemos ver Jovellanos, aún sabiéndose con autoridad, no adopta un tono de altivez y sabiduría absoluta, sino que habla de tu a tu, con cuidado en todo lo que dice pero sin encumbrarse, porque sabe que sólo de este modo logrará llegar a su lector influyéndole, no cabe duda, pero nunca anulando lo que su receptor puede saber o pensar, haciendo suya esa máxima del género ensayístico, de diálogo continuado en estilo sencillo sobre temas diversos de actualidad, de cierta polémica en algún caso, con el que se pretende convencer y activar la capacidad crítica del receptor más diverso. Máxima ilustrada tras la cual se puede ver en don Gaspar su actitud ensayística.

${ }^{38}$ Op. cit. (Bellver) 30 de diciembre de 1804, de Jovellanos a Carlos González de Posada. 